\title{
EL CINE COMO PATRIMONIO CULTURAL: EL CASO DE LA FILMOTECA ESPAÑOLA
}

\author{
Valeriano Durán Manso \\ Universidad de Cádiz, España \\ valeriano.duran@uca.es
}

\section{RESUMEN}

El cine constituye uno de los medios de comunicación que ha tenido un mayor impacto social, cultural e histórico en el siglo XX. Su nacimiento supuso una notable innovación tecnológica y desde entonces, su desarrollo ha estado ligado al ámbito del espectáculo; no tardando en estructurarse como una industria cultural alternativa a otras como el teatro por su carácter popular. Así, representa y construye la personalidad, el pasado y la historia de una sociedad, adquiriendo un valor documental que es necesario analizar y preservar. Por ello, forma parte del patrimonio cultural como recogen instituciones como la UNESCO y la Unión Europea, así como leyes de diversos países, pudiéndose distinguir entre patrimonio cinematográfico y patrimonio fílmico. Con el objetivo de reflexionar sobre la conservación del cine, este artículo pretende destacar aquellos aspectos que hacen posible su supervivencia, como la restauración y la difusión. Para ello, se realizará una aproximación al caso de la Filmoteca Española.

Palabras clave: Cine. Patrimonio cultural. Filmoteca Española.

\section{CINEMA AS A CULTURAL HERITAGE: THE CASE OF FILMOTECA ESPAÑOLA}

\begin{abstract}
Cinema is one of the media that has had a greater impact social, cultural, and historical in the 20th century. His birth was a remarkable technological innovation and, since then, its development has been linked to the scope of the entertainment; not taking long to be structured as a cultural industry alternative to others, as the theater, by its popular character. Thus, it represents and builds personality, the past and the history of a society acquiring a documentary value that must be discussed and preserve. Therefore, it is part of the cultural heritage, as they collect institutions such as UNESCO and the European Union, and laws of different countries, and to differentiate between cinematographic heritage and the film heritage. With the aim of reflecting on the conservation of the cinema, this article aims to highlight those aspects that make it possible their survival, such as the restoration and dissemination. To do this, there will be an approximation to the case of Filmoteca Española.
\end{abstract}

Keywords: Cinema. Cultural heritage. Filmoteca Española.

\section{O FILME COMO PATRIMÔNIO CULTURAL: O CASO DO FILMOTECA ESPAÑOLA}

\section{RESUMO}

Cinema é um dos meios de comunicação que tem tido maior impacto social, cultural e histórico no século XX. Seu nascimento foi uma notável inovação tecnológica e, desde então, seu desenvolvimento tem sido asociado ao campo do entretenimiento; não tendo estrutura é como indústria cultural alternativa para outros, como o teatro, por seu caráter popular. Assim, 
representa e constrói a personalidade, o passado e a história de uma sociedade e adquire um valor documental que deve ser discutido e preservar. Portanto, é parte do património cultural, como eles coletam as instituições como a UNESCO e a União Europeia e as leis dos diferentes países, sendo capaz de distinguir entre o património cinematográfico e o património fílmico. Com o objetivo de refletir sobre a conservação do filme, este artigo visa destacar os aspectos que tornam possível a sua sobrevivência, tais como a restauração e a divulgação. Para fazer isso, vai haver uma aproximação para o caso da Filmoteca Española.

Palavras-chave: Cinema; Património cultural; Filmoteca Española.

\title{
LE CINÉMA COMME UN PATRIMOINE CULTUREL: LE CAS DE LA FILMOTECA ESPAÑOLA
}

\begin{abstract}
RÉSUMÉ
Cinéma est un des médias qui a eu un plus grand impact social, culturel et historique du XXe siècle. Sa naissance a été une innovation technologique remarquable et depuis lors, son développement a été lié au domaine du divertissement; ne pas prendre de temps à être structurée comme une alternative culturelle à d'autres, comme le théâtre, par son caractère populaire. Ainsi, il représente et construit la personnalité, le passé et l'histoire d'une société, acquérant une valeur documentaire qui doit être discutée et préserver. Donc, il fait partie du patrimoine culturel comme collectionne les institutions comme l'UNESCO et l'Union européenne et les lois des différents pays et faire la différence entre le patrimoine cinématographique et le patrimoine filmique. Dans le but de réfléchir sur la conservation du film, cet article vise à souligner les aspects qui rendent possible à leur survie, tels que la restauration et la diffusion. À cette fin, on procédera à un rapprochement au cas de la Filmoteca Española.
\end{abstract}

Mots-clés: Cinéma. Patrimoine culturel. Filmoteca Española.

\section{INTRODUCCIÓN}

Disponer de información en el presente no garantiza su conservación para el futuro. Esta idea es aplicable al ámbito cinematográfico por la debilidad que presentan los soportes fílmicos y la dificultad que conlleva su correcta preservación. Desde los inicios del cine, existe a nivel mundial un elevado porcentaje de filmes perdidos, bien por los habituales incendios que se originaban durante las exhibiciones -el nitrato de celulosa, uno de los soportes más utilizados, era altamente inflamable-, o bien porque se han destruido por asuntos políticos o económicas. A este respecto, es necesario destacar la fragilidad que identifica a las películas, así como los daños más graves de su historia:

Debido a sus características físicas están permanentemente amenazadas por el deterioro, e incluso abocadas a la pura y simple destrucción, especialmente a partir del momento en que dejan de ser rentables para la industria. Esta amenaza pesa no sólo sobre cada película una vez terminada su explotación comercial. Todas las películas de una época pueden estar en peligro: un simple cambio tecnológico, el 
paso del cine mudo al sonoro en los años 30, o la utilización de los nuevos soportes de seguridad en los años 50, ha provocado pérdidas irreparables para el patrimonio cinematográfico mundial. (VV.AA., 1995, p. 47).

Además, con el paso del tiempo el material fílmico puede sufrir un importante deterioro, mediante perforaciones, mutilaciones, contracciones o la descomposición del soporte, lo que supone el fatal desenlace del filme. Cuestiones tan significativas como el sonido o el color -normalmente, afectado por la temperatura, la polución, la humedad del aire y la luz-, presentan también elementos de riesgo para la supervivencia de los filmes, sobre todo de los más antiguos, y, especialmente, los mudos. La decadencia de estos aspectos técnicos conlleva irremediablemente la destrucción de la imagen, $\mathrm{y}$, con ello, la pérdida de la historia, la narración y los personajes; en definitiva, el testimonio del pasado que constituye la memoria audiovisual de un pueblo. Este es el punto de partida que marcó el nacimiento de las primeras filmotecas y originó la consideración necesaria del cine como patrimonio cultural que debe ser conservado para su difusión.

En esta tarea, hay que advertir dos cuestiones. La primera es que "conforme los avances técnicos y artísticos del cine se van acrecentando, las viejas películas pierden todo su valor para la industria del espectáculo, dejan de ser una mercancía rentable y se destruyen para el aprovechamiento de sus desechos" (SORIA, 2005, p 21-22), mientras que la segunda dice que "ni los materiales ni los procesos de elaboración de una película fueron pensados para su conservación a largo plazo" (PIQUERAS, 1995, p. 8). Ambas son esenciales para entender la importancia de recuperar, restaurar y preservar los filmes. Por otra parte, la conservación de las películas -tanto de carácter documental como de ficción-, alude a la búsqueda, la conservación, la custodia y la difusión de toda aquella documentación relacionada con ellas. Este material también forma parte del patrimonio cultural y, en concreto, del audiovisual -que integra a medios de comunicación como la radio o la televisión-, pues, sin duda, "es importante para entender el pasado, el presente o la sociedad del mañana” (MARCOS RECIO, 2013, p. 13). De esta manera, las tareas de las filmotecas se enfocan en localizar, analizar, restaurar, conservar, catalogar, difundir y reutilizar los materiales fílmicos, y se erigen como el nexo entre este patrimonio -que atiende a aspectos de tipo artístico, cultural, histórico y educativo-, y la sociedad:

Los grandes avances de la humanidad son fruto de la educación, del conocimiento, de la investigación y, sobre todo, del compromiso del ser humano para conservar parte de su historia. Una idea es importante cuando se pone en práctica, y más cuando alguien la plasma en un libro y se puede utilizar siglos después. Si nadie la escribe, si nadie la conserva en una biblioteca, si nadie hace un esfuerzo para que otras personas la conozcan, esa idea termina por desaparecer. El compromiso para 
que llegue a otras generaciones esa idea es lo que permite que avance la sociedad. (MARCOS RECIO, 2013, p. 12).

En este sentido, el cine no sólo se puede observar como una serie de secuencias que están hiladas con un guión, sino que, desde la perspectiva de los historiadores y de los antropólogos, "ofrece imágenes que sociológicamente ilustran las preocupaciones, las costumbres, los objetos y las formas de entender la vida de una época" (CARIDAD et al., 2011, p. 15). Por esta capacidad testimonial, se puede indicar que "es un medio que guarda importantes riquezas para el conocimiento futuro de la sociedad, ya que en sus películas se puede estudiar [...] una parte de la historia” (MARCOS RECIO, 2013, p. 19). No obstante, resulta oportuno reflexionar sobre la relevancia de la conservación del cine -a nivel tecnológico y cultural-, para su permanencia en la memoria, pues sólo así se podrá evitar su pérdida, al igual que sucede con la arquitectura o la pintura, que, por una parte, indican el talante de la civilización que las creó y, por otra, su valor artístico. Como ocurre en ambos estilos, "es preciso localizar, identificar y recuperar materiales perdidos, es preciso restaurarlos o, al menos, detener su deterioro y es preciso, por encima de todo, preservarlos de todos los posibles daños que les puedan afectar para después exhibirlos y difundirlos" (DEL VALLE GASTAMINZA, 2013, p. 122).

Aunque el patrimonio audiovisual abarca tanto el cine como la televisión, la fotografía, los fondos musicales, los archivos radiofónicos y la publicidad (MIMOSA y PATÓN RODRÍGUEZ, 2014), este artículo se centra en el patrimonio cinematográfico. Para su preservación, restauración y difusión, las instituciones más adecuadas son las de carácter público presentes en cada país, como las filmotecas, aunque algunas privadas, como fundaciones o museos, también desarrollan un importante trabajo. En el caso de España, además de la significativa labor que llevan a cabo las situadas en las distintas comunidades autónomas, destaca especialmente la Filmoteca Española, que, a su vez, se erige como el modelo a seguir por la demás para la conservación del cine. No obstante, otros organismos públicos, como las Universidades, bibliotecas y archivos nacionales, temáticos o municipales (EDMONSON, 2004), desarrollan también una destacada tarea en lo referente a la localización y difusión del material fílmico, aunque las filmotecas son las que realizan una función más específica al incluir los trabajos de restauración:

La historia de la documentación cinematográfica está directamente ligada a la historia de las filmotecas. Las filmotecas son organismos encargados de la localización, recuperación, preservación, restauración, catalogación y difusión del patrimonio cinematográfico y de toda la documentación relativa al cine. Eso incluye los objetos, aparatos y otros elementos relacionados con la práctica cinematográfica. (HERNÁNDEZ PÉREZ, 2011, p. 26-27). 
Desde estas consideraciones, este trabajo pretende poner en valor el papel del cine como testigo de la evolución de la sociedad y como expresión artística contemporánea, y reflexionar sobre su carácter patrimonial, su preservación y su difusión. Para ello, se ha optado por seguir los planteamientos de una metodología cualitativa que se ha centrado, en primer lugar, en el análisis bibliográfico y documental de las aportaciones de diversos expertos sobre el patrimonio cultural y audiovisual, las normativas referentes a la protección del cine y el origen de las filmotecas, $\mathrm{y}$, en segundo lugar, en el uso del estudio de caso como método de investigación, tomando a la Filmoteca Española como objeto de estudio, descripción y análisis. Justamente, este planteamiento metodológico, caracterizado por un enfoque claramente idiográfico, está orientado a conocer y comprender la realidad singular de la mencionada filmoteca.

\section{EL PATRIMONIO CULTURAL: UNA APROXIMACIÓN AUDIOVISUAL}

El patrimonio cultural tiene sus raíces en la identidad y habla de las huellas del pasado. Normalmente, alude al valor de carácter histórico, artístico o social de un bien cultural (DÍAZ CERVANTES, 2014), que, en muchos casos, suele combinar los tres. Así, la escultura, los edificios, la pintura, las monedas, las danzas tradicionales, la gastronomía o los parajes naturales, entre otros muchos bienes, conforman el patrimonio cultural de un pueblo o nación. En este sentido, desde el siglo XIX, en concreto con la creación de la fotografía, la imagen constituye en uno de los elementos culturales más potentes de la historia contemporánea. Esta idea se afianzó con la invención de las imágenes en movimiento, es decir, del cine, y, especialmente, con la incorporación del sonido, bien mediante acompañamiento musical durante el periodo silente, o bien en los filmes sonoros. Su carácter patrimonial reside, en buena medida, en el conocimiento que la sociedad posee de la historia, o de una época determinada, mediante las imágenes y los sonidos; lo que se conoce como memoria audiovisual (DÍAZ CERVANTES, 2014). Debido al conjunto de aspectos históricos, artísticos y, cómo no, sociológicos, que están vinculados al cine desde su nacimiento, se puede afirmar lo siguiente:

Si partimos de la consideración del patrimonio cultural como toda aquella manifestación humana, pasada o presente, tangible o intangible, a la que una colectividad reconoce como representativa de su identidad y vehículo de su memoria (histórica, social, cultural, ideológica), resulta evidente que el cine es uno más de los patrimonios que la sociedad contemporánea debe proteger, conservar, recuperar, investigar y difundir. (RODRÍGUEZ ORTEGA, 2011, p. 16). 
La idea y la salvaguarda del patrimonio cultural, y del patrimonio audiovisual mucho más específico-, se deben a la UNESCO, una institución que considera que "el patrimonio cultural son los bienes que una nación obtiene por herencia” (HERNÁNDEZ PÉREZ, 2011, p. 25). En este sentido, engloba distintos aspectos que pueden organizarse en patrimonio cultural material; patrimonio cultural mueble, que acoge desde pinturas a esculturas o manuscritos; patrimonio cultural inmueble, donde se ubican monumentos y ruinas arqueológicas, entre otros aspectos; patrimonio cultural subacuático, en el que se enmarcan los restos de naufragios y elementos que han quedado sumergidos; patrimonio cultural inmaterial, es decir, fiestas, ritos o espectáculos; patrimonio natural, que abarca sitios naturales que conforman paisajes culturales o formaciones de índole geológica o física, entre otras; o, patrimonio en situaciones de conflicto armado, que es uno de los más sensibles. Estas categorías fueron acuñadas por Ray Edmondson, quien, además, definió los elementos que configuraban y determinaban el patrimonio audiovisual:

Las connotaciones y el alcance de este concepto varían de una cultura a otra, de un país a otro y de una institución a otra, pero en esencia viene a decir que los archivos audiovisuales deben contextualizar las grabaciones, programas y películas con que cuentan reuniendo o protegiendo, según el caso, una serie de objetos, conocimientos y técnicas conexos. (EDMONDSON, 2004, p. 24).

Asimismo, este autor señala que el patrimonio audiovisual abarca grabaciones cinematográficas, sonoras o televisivas que incluyan imágenes en movimiento -tanto en soporte fílmico como digital-, es decir, la película; los objetos materiales e inmateriales relacionados con los documentos audiovisuales, a nivel técnico, industrial, histórico y cultural, tales como guiones, fotografías, carteles, vestuarios, o los textos periodísticos y aquellos vinculados con la censura, entre otros; el mantenimiento de técnicas en desuso relacionadas con la producción, la reproducción o la exhibición del cine; y, por último, el material no literario o gráfico, como fotografías, manuscritos, diapositivas o mapas, vinculado a la labor cinematográfica. A raíz de esta definición y categorías, Edmondson concretó el archivo audiovisual como "una organización o un departamento de una organización cuyo cometido, que podrá estar establecido por ley, consiste en facilitar el acceso a una colección de documentos audiovisuales y del patrimonio audiovisual mediante actividades de acopio, gestión, conservación y promoción" (2004, p. 27).

En este sentido, la documentación audiovisual adquiere una gran importancia por su capacidad para catalogar y hacer accesible este patrimonio a la sociedad. Ambas tareas se 
antojan imprescindibles para la preservación de la historia y de la cultura y, también, para facilitar el trabajo de estudiosos, analistas e investigadores de la materia, tanto en el ámbito académico como en la práctica profesional del audiovisual. Además, no hacerlo conllevaría graves consecuencias para el conocimiento del patrimonio, pues "el peligro puede no ser otro que el olvido -la forma más radical y devastadora de la pérdida- o la repetición -la forma más cruel con que lo sucedido se venga de la ignorancia y la incomprensión" (SÁNCHEZBIOSCA y TRANCHE, 1993, p. 19). Por ello, es necesario que se localice, se clasifique y se proteja para poder ser transmitido:

La documentación audiovisual da un servicio general actual a la sociedad en cuanto
mantiene unos fragmentos audiovisuales de la vida real, ciertamente con toda la
mediación e interpretación que puedan hacer la técnica y narrativa audiovisuales,
pero al fin y al cabo la sociedad quiere ver las imágenes y escuchar los sonidos de
una realidad próxima a su vida, a su entorno, a su historia [...] Posee un valor
incalculable para los investigadores de diferentes campos: comunicativo, histórico,
sociológico, antropológico, etc. (CEBRIÁN HERREROS, 2011, p. 10).

Cuando se habla de patrimonio audiovisual se tiende a pensar en el cine, sobre todo de ficción, y en la televisión; dos manifestaciones dominadas por las imágenes en movimiento que suelen estar sustentadas por industrias potentes del entretenimiento y que han protagonizado el siglo XX. No obstante, el cine documental, el de vanguardia, el independiente, los anuncios publicitarios, o los informativos, también tienen un valor muy significativo para evidenciar y explicar la vida (HERNÁNDEZ PÉREZ, 2011). De esta manera, el valor patrimonial del audiovisual debe unir ambas esferas: la artística, que corresponde al estilo, lo visual o la narrativa, entre otros aspectos, y la testimonial, es decir, aquella que se aproxima a la realidad histórica y social mediante las imágenes que se transmiten desde la pantalla. El cine conlleva una destacada dimensión cultural, tanto en lo que respecta a la alta cultura como a su carácter popular, y "contribuye en el avance científico pues su contenido audiovisual es una fuente para la investigación de la vida de una época y sus aportes en la sociedad actual" (DÍAZ CERVANTES, 2014). En cierto modo, la imagen supone la única forma de captar el instante y verificar lo que ha existido, y esto incide notablemente en el valor del cine como "patrimonio cultural en cuanto a que, bajo cualquiera de sus manifestaciones, remite a una expresión humana y está fuertemente vinculado a la sociedad que lo produce" (VALDÉS, 2015). 


\section{EL VALOR CULTURAL, PATRIMONIAL Y EDUCATIVO DEL CINE}

El enfoque documental y testimonial del cine empezó el 28 de diciembre de 1895 con la primera exhibición del cinematógrafo ante el público del Salon Indien du Grand Café del Boulevard des Capucines de París. Las diez películas que proyectaron los hermanos Auguste y Louis Lumière recogían la realidad del momento en escenas cotidianas donde los personajes no eran actores. Así se reflejó en la primera, Salida de los obreros de la fábrica (La Sortie des usines Lumière), cuya acción, de 46 segundos de duración, se centraba en los trabajadores de la fábrica Lumière de Lyon al salir del trabajo. Con la excepción de $E l$ regador regado (L'arrosseur arrosé), que contaba con argumento y no parecía documental, todas mostraban una situación habitual mediante la cámara fija. De esta manera, se constata que el cine no apostó desde el principio por la ficción, sino por un estilo que estaba ligado a la plasmación de la vida diaria. Por ello, los primeros filmes tienen un valioso valor patrimonial al reflejar a la sociedad francesa de 1895. Así, "el cine como documento de la realidad, como reflejo de la vida, como información, nace con los Lumière" (DEL VALLE GASTAMINZA, 2013, p. 112).

Este apunte histórico destaca el género utilizado por los pioneros, e invita a la reflexión sobre cómo eran las personas que aparecían en pantalla, qué tareas realizaban o qué aspecto tenían. De esta forma, a la dimensión tecnológica del aparato se sumaban el papel testimonial de los filmes y el contexto sociocultural que reflejaban, ya que "el valor de las mismas no residía sólo en el soporte material sino en lo que mostraban [...]; los obreros saliendo de una fábrica ilustraban no sólo un hecho de la época sino sus costumbres, sus vestimentas" (CARIDAD et al., 2011, p. 15). A partir de entonces, el proceso creativo del cine se desarrolló con un lenguaje propio -el cinematográfico-, que el público aprendió, la apuesta por la estructura narrativa clásica, y una estética que le otorgaba carácter visual. Por ello, "en la consideración de la condición patrimonial del cine hay que tener en cuenta esta 'complejidad' o, si se quiere, poliedricidad: objeto, documento-contenido, expresión creativa mediante un lenguaje específico, secuencia visual en un espacio y en un tiempo determinado" (RODRÍGUEZ ORTEGA, 2011, p. 17).

A este respecto, es necesario distinguir entre lo que se considera patrimonio fílmico y patrimonio cinematográfico, para poder comprender qué ámbitos protege cada uno. El primero alude al conjunto tangible de películas que deben ser preservadas por el papel que ocupan en la historia del cine, el valor que tienen como reflejo de la sociedad o por representar un momento histórico o artístico de especial relevancia, entre otros aspectos. Sin 
embargo, en 2004 fue reconocido el término patrimonio cinematográfico con una dimensión más amplia que el anterior. Así, mientras el fílmico se refería estrictamente a las películas, el segundo incluía también a todos aquellos elementos que forman parte del proceso cinematográfico, como las distintas maquinarias, los espacios de exhibición, los carteles, el vestuario o los estudios (RODRÍGUEZ ORTEGA, 2011).

El valor patrimonial del cine obtuvo su primer reconocimiento oficial e internacional en 1981, mediante el documento Recomendación sobre la salvaguarda y la construcción de las imágenes en movimiento (RSCIM), elaborado por la UNESCO y aprobado en la XXI Sesión de la Conferencia General (Belgrado, 23 septiembre-29 octubre de 1980). Este decisivo texto "atribuye competencias de los Estados en materia de legislación y remarca la libertad de éstos para decidir cómo hacerlo, aunque fomenta la cooperación y el consenso internacionales y señala como punto de partida el Derecho Internacional" (DEL VALLE GASTAMINZA, 2013, p. 115). Asimismo, destaca también la relevancia del patrimonio fílmico, diferenciándolo de otros elementos integrantes del patrimonio cultural. Con estas premisas, esta recomendación fijó un total de catorce pautas que reconocían el valor cultural del cine (UNESCO, 1981, p. 167), entre las que destacan las siguientes por su estrecha relación con el sentido patrimonial del mismo:

- Las imágenes en movimiento son una expresión de la personalidad cultural de los pueblos y, debido a su valor educativo, cultural, artístico, científico e histórico, forman parte integrante del patrimonio cultural de una nación. [...]

- Es necesario que cada Estado tome medidas complementarias adecuadas encaminadas a garantizar la salvaguardia y la conservación para la posteridad de esa parte especialmente frágil de su patrimonio cultural, del mismo modo que se salvaguardan y conservan otras formas de bienes culturales como fuente de enriquecimiento para las generaciones presentes y futuras. [...]

- Las imágenes en movimiento creadas por los pueblos de todo el mundo forman parte del patrimonio de la humanidad en su conjunto y, por consiguiente, procede fomentar una más estrecha cooperación internacional para salvaguardar y conservar esos testimonios insustituibles.

El compromiso de la UNESCO en esta materia marcó el considerable aumento del interés por los archivos audiovisuales que se produjo a mediados de la década de los ochenta. Los factores que tuvieron un papel más decisivo en esta toma de conciencia fueron las distintas recomendaciones de esta institución, especialmente de la RSCIM; el incremento de horas de emisión televisiva debido a cuestiones comerciales, que fueron cubiertas de forma generalizada por material de archivo, lo que supuso la recuperación de documentales inéditos para el público y de películas antiguas que no se exhibían desde que fueron estrenadas en el cine; y, por último, las campañas de concienciación sobre la importancia de conservar los documentos audiovisuales, que coincidieron con los incendios ocasionados en la Cineteca 
Nacional de México (1982), la Cinémathèque Française (1997) y otros originados en importantes archivos de Estados Unidos y Japón que provocaron numerosas pérdidas de material audiovisual (HERNÁNDEZ PÉREZ, 2011). Estos elementos pusieron de manifiesto el destacado papel que las instituciones y la televisión desempeñaron en estos años para la toma de conciencia, la protección y la difusión del cine como patrimonio cultural que debe ser preservado.

No obstante, hasta 1995, con motivo del centenario del cine, la UNESCO no defendió por primera vez la necesidad de su conservación y recuperación, “apuntalando así su significación cultural en cuanto expresión de un tiempo, un contexto, una mentalidad, una ideología y un entramado social” (RODRÍGUEZ ORTEGA, 2011, p. 19). Así, destacó también que el cine se configuraba como un medio de importante potencial educativo por su carácter histórico y su papel de testigo en la evolución y cambio de la sociedad. En esta línea, “el reconocimiento del carácter patrimonial del producto fílmico va unido, pues, en primera instancia, al reconocimiento de su valor documental como memoria del mundo y reflejo de la contemporaneidad" (RODRÍGUEZ ORTEGA, 2011, p. 19). Como prueba de la concienciación realizada por esta institución, el 27 de octubre de 2007 la UNESCO celebró el primer Día Mundial del Patrimonio Audiovisual.

Por su parte, la Unión Europea ha desarrollado a partir del nuevo siglo diversos documentos e iniciativas que destacan el valor patrimonial del cine como referente de la identidad y solicitan medidas encaminadas a su protección y difusión. En esta línea, se enmarcan, entre otros, el Convenio europeo para proteger el patrimonio audiovisual, que aprobó el Consejo de Europa en 2001 y fijaba que cada país debía imponer el depósito legal obligatorio de aquellos filmes que formaban parte de su patrimonio audiovisual y se habían producido o coproducido en su territorio (HERNÁNDEZ PÉREZ, 2011); el informe sobre la Protección del Patrimonio Cinematográfico en Europa, publicado por el Observatorio Europeo del Audiovisual en 2004 -que recoge las líneas desarrolladas por la institución en la materia hasta la fecha-; y las Recomendaciones del Parlamento y del Consejo Europeo sobre el patrimonio filmico y la competitividad de las actividades industriales relacionadas, de 2005, "que fomenta toda actividad orientada a la mejor conservación del material cinematográfico, reconociendo su fragilidad y el peligroso estado de conservación en que se encuentran la mayoría de fondos ya catalogados" (DEL VALLE GASTAMINZA, 2013, p. 115). Asimismo, en los últimos años el Consejo Europeo se ha pronunciado también sobre la digitalización y la accesibilidad en línea del material cultural y la conservación digital, en 
2006; las políticas cinematográficas nacionales y la diversidad de las expresiones culturales, en 2009; o el patrimonio cinematográfico europeo y los retos de la era digital, en 2010.

\section{EL PAPEL DE LAS FILMOTECAS: DE LA CONSERVACIÓN A LA DIFUSIÓN}

La primera aproximación a la idea de archivo cinematográfico acaeció en 1898 por parte del fotógrafo, e incipiente cineasta, de origen polaco Boleslaw Matuszewski. Unas imágenes que tomó de la visita oficial a Rusia del presidente de Francia Félix Faure le sirvieron como testimonio ante una serie de acusaciones falsas realizadas por parte del canciller alemán Otto Von Bismarck. Este suceso lo llevó a meditar sobre la necesidad de salvaguardar los documentos cinematográficos por el valor histórico que encierran. Además, ese mismo año publicó en París un manifiesto en el que solicitaba la creación de una red de archivos a nivel mundial para poder obtener, comercializar y conservar el nuevo producto cinematográfico (HERNÁNDEZ PÉREZ, 2011). De esta manera, se puede considerar que Matuszewski fue un pionero en esta tarea:

\footnotetext{
En sus actividades y en sus escritos teóricos, muchos años antes de la aparición del primer archivo cinematográfico, sienta las bases de la conservación cinematográfica, determinando que la actividad de coleccionar películas debe ser un servicio público, en el que se impliquen distintos organismos de la Administración; asimismo señala por primera vez la idea de que debe haber un depósito legal para la cinematografía, propone que los archivos estén abiertos al público y prevé además salas de proyección. (DEL VALLE GASTAMINZA, 2013, p. 113).
}

Matuszewski se refiere aquí al cine documental y se opone a la conservación del cine de ficción, marcando así la distancia entre el filme como documento y el filme como obra artística. En estos años existía una oposición generalizada a la protección del cine de fícción, quizá por tener un acusado carácter popular y exhibirse normalmente en cafés o barracas de feria hasta la configuración del cine comercial como industria en los años diez. No obstante, los Lumière entregaron en un Tribunal de Lyon sus primeras películas, filmadas entre $1895 \mathrm{y}$ 1897; sin duda, una prueba de la concienciación sobre la necesidad de preservar sus obras. Además, en 1894, en Estados Unidos se empezaron a consignar los primeros documentos fotográficos y cinematográficos en el Copyright Office de Washington. En esta línea, resulta también reseñable que en 1900 el Congreso Etnográfico de París aceptara una recomendación sobre la incorporación de películas en los fondos de todos los museos antropológicos (HERNÁNDEZ PÉREZ, 2011). 
Las iniciativas de conservación de películas no tuvieron un amplio desarrollo hasta la llegada del sonoro en 1927, y esto indica que buena parte de la producción del cine silente desapareció. Las primeras filmotecas aparecieron en la década de los treinta ante la necesidad de preservar aquellos títulos del periodo mudo que habían perdido valor comercial frente al recién llegado sonoro, pero que, sin embargo, habían adquirido un valor histórico-social (RODRÍGUEZ ORTEGA, 2011). Así, en 1933 se inaugura en Estocolmo el Svenska Filmsandfundet Arkiv, por iniciativa privada; en 1934 el ministro de Información y Propaganda alemán, Joseph Goebbles, propició el Reichfilmarchiv; en 1935 nacen el National Film Archive de Londres y el archivo de cine del Museum of Modern Art (MOMA) de Nueva York; y en 1936 aparece la Cinémathèque Française en París. La mayoría de estos primeros archivos surgieron por iniciativa privada, aunque los casos alemán y británico constataron la necesidad de marcar políticas estatales en la conservación del cine. Los cuatro últimos crearon en 1938 en París el principal espacio para la protección del cine, la Federación Internacional de Archivos Fílmicos (FIAF), que debido a la II Guerra Mundial no pudo iniciar su trabajo hasta 1946 (HERNÁNDEZ PÉREZ, 2011). Del Valle Gastaminza (2013, p. 114) recoge sus objetivos:

1. Favorecer la recuperación y la conservación de todas las películas, consideradas como obras de arte y/o como documentos históricos.

2. Facilitar la recuperación y la conservación de los materiales de documentación de todo tipo relacionados con las películas.

3. Promover en todos los países la creación y el desarrollo de archivos de filmes consagrados a la salvaguarda del patrimonio cinematográfico nacional e internacional.

4. Desarrollar la cooperación entre sus miembros y asegurar la disponibilidad de las películas y de los documentos a nivel internacional.

5. Promover el arte y la cultura del cine y las investigaciones históricas sobre todos los aspectos del cine.

El nacimiento de la FIAF propició el desarrollo de filmotecas a nivel mundial; de hecho, en la actualidad -cuya sede se sitúa en Bruselas-, acoge más de 150 de un total de 77 países distintos. En este marco, se inauguró en 1953 la Filmoteca Nacional, que en 1956 se integró en la FIAF y en 1982 pasó a denominarse Filmoteca Española. Por otra parte, no fue hasta la década de los ochenta cuando las filmotecas empezaron a tener en España un gran crecimiento y surgieron políticas de carácter público enfocadas al patrimonio fílmico y su protección. A este respecto, destacó especialmente la Ley 16/1985, de 25 de junio, del Patrimonio Histórico Español (LPHE), que aunque no se refería de forma específica al patrimonio cinematográfico, recogía lo siguiente: 
El patrimonio histórico español se define como el conjunto que integran los inmuebles y objetos muebles de interés artístico, histórico, paleontológico, arqueológico, etnográfico científico o técnico. También forman parte del mismo el patrimonio documental y bibliográfico de los museos, archivos y bibliotecas. En este sentido, en el artículo 50 de la mencionada ley se indica que las bibliotecas y colecciones bibliográficas de escritura manuscrita e impresa, formarán parte del Patrimonio Bibliográfico. (MARCOS RECIO, 2013, p. 19).

Esta ley fijaba que el patrimonio cinematográfico formaba parte del patrimonio documental y bibliográfico, y quedaba estrictamente vinculado a su vertiente fílmica. Así, se reconocía a la película como documento y se aseguraba su protección, pero no la de otros materiales que conforman el patrimonio cinematográfico. Esta visión cambió, o evolucionó, poco después, en 1987, con el Real Decreto 7/1987, 1450, de 10 de enero, en el que se codificó la organización y la actividad de las filmotecas. Esta disposición fijó que el concepto de patrimonio cinematográfico comprendía todos aquellos aspectos vinculados al cine. Las leyes posteriores han seguido esta línea, como la Ley 15/2001, de 9 de junio, de Fomento y Promoción de la Cinematografia y el Sector Audiovisual, o la ley del cine de 28 de diciembre (55/2007). Ambas recogen que el carácter patrimonial del cine se constituye en función de los valores artísticos y culturales, así que al valor documental y testimonial que tenían los filmes, se sumaba su configuración como obra creativa. Además, la última indicaba que el Estado era el encargado de establecer las medidas encaminadas a la conservación del patrimonio cinematográfico y de promover su difusión a nivel nacional e internacional. Sin embargo, insistía en que el Instituto de la Cinematografía y de las Artes Audiovisuales (ICAA) era el organismo indicado para la protección y transmisión de este patrimonio mediante la Filmoteca Nacional; una idea que ya aparecía recogida en el Real Decreto 7/1987. Así, se reforzaba lo establecido.

En este marco, proliferaron las filmotecas de la mayoría de las comunidades autónomas, aunque ya existían algunas destacadas como la Filmoteca Vasca (1978); la Filmoteca de Catalunya (1981), que tenía su origen en una delegación de la Filmoteca Nacional creada en 1972; o la Filmoteca de Zaragoza (1981) (PÉREZ MILLÁN, 2005). La mayoría se dedica a la recuperación y la conservación del patrimonio fílmico de cada comunidad. Algunas se centran estrictamente en las tareas de investigación, restauración y archivo, mientras que otras incluyen también la difusión; una labor ineludible para dar a conocer el patrimonio a la sociedad y fomentar su función educativa. Además, suelen colaborar con la Filmoteca Española. En cuanto a la exhibición, algunas desempeñan también el rol de salas de cine alternativas ante la paulatina desaparición de numerosos cines o cineclubs. De esta manera, manifiestan su compromiso por la divulgación de la cultura, pues 
la mayoría de las películas que programan -tanto clásicas como actuales-, no tienen cabida en los multicines que dominan el panorama cinematográfico desde hace varias décadas. Este es el caso de la Filmoteca de Andalucía -fundada en 1989-, o de una de las más recientes, la de Extremadura -creada en 2003-, mientras que otras como las de Castilla y León o la ya citada del País Vasco representan el modelo clásico:

Las filmotecas constituyen hoy archivos fílmicos que tienen como objetivo recuperar, investigar y conservar el patrimonio del cine, así como llevar a cabo actividades encaminadas a su difusión y acceso. Que existan las filmotecas hace posible que podamos encontrar y que podamos recuperar parte de nuestra memoria colectiva. (RODRÍGUEZ ORTEGA, 2011, p. 23).

Desde estas consideraciones, las filmotecas son las encargadas de recuperar y cuidar los títulos más significativos de las cinematografías nacionales, poner en valor las películas más destacadas de la historia del cine, $\mathrm{y}$, especialmente, dar voz en la actualidad a aquellas cinematografías silenciadas, postergadas y hasta olvidadas, que existieron y existen, pero que están fuera de los circuitos comerciales. En este sentido, el silencio fílmico adquiere voz en estos espacios de encuentro con la memoria para enseñar a los espectadores que hay otras historias, otras formas y, en definitiva, otras culturas, de las que también podemos y debemos aprender, crecer y disfrutar. Por último, es necesario destacar que en 2013 la FIAF pidió a la UNESCO que la cinematografía analógica fuera declarada Patrimonio Universal de la Humanidad; un importante paso para la preservación mundial del celuloide y del cine (EFE, 2013).

\section{LA FILMOTECA ESPAÑOLA: EL BALUARTE DEL PATRIMONIO FÍLMiCO ESPAÑOL}

La Filmoteca Española constituye el referente de las filmotecas en España y desde su origen sigue el modelo de sus precedentes europeas. Situada en Madrid, ejerce las tres actividades principales que distinguen a las filmotecas de otros espacios dedicados a las tareas de registro o catalogación de material -como las bibliotecas-, la localización, la recuperación o restauración y la conservación (HERNÁNDEZ PÉREZ, 2011). Este archivo histórico tiene como fin custodiar el patrimonio fílmico español.

\section{Aproximación histórica e instalaciones}


Esta institución es una Subdirección General del Instituto de la Cinematografía y de las Artes Audiovisuales del Ministerio de Cultura, que se creó el 13 de febrero de 1953 mediante una Orden Ministerial con el nombre de Filmoteca Nacional de España. Su nacimiento se produjo bastante después de la aparición de las primeras filmotecas europeas, pero sucedió el año que España entró en la UNESCO y firmó el Concordato con el Vaticano y, además, los Pactos de Madrid con Estados Unidos (PRADO, 2005). Aunque existe un antecedente en los primeros archivos de documentos cinematográficos creados a finales de la década de los treinta (HERNÁNDEZ PÉREZ, 2011), no es hasta su aparición cuando se produjo un notable desarrollo en la protección del cine. Desde sus inicios, "gestiona un archivo histórico que custodia el patrimonio fílmico español y tiene, entre sus funciones, la recuperación, preservación, restauración, documentación, catalogación y difusión del patrimonio cinematográfico, así como de cualquier otro elemento relacionado con la práctica de la cinematografía" (DE LA FUENTE, 2015, p. 74). Sus fondos están compuestos principalmente por películas españolas, debido a que en 1964 se fijó de manera obligatoria que había que depositar en la filmoteca una copia de todas las películas que habían recibido alguna subvención de la Dirección General de Cinematografía (PRADO, 2005). Además de favorecer la producción cinematográfica, esta iniciativa ha servido para preservar las copias originales de la mayoría de los filmes producidos en España desde entonces; en total más de medio siglo salvaguardado.

La filmoteca consta de tres dependencias. La primera es el Palacio de Perales, ubicado en el centro de Madrid, que acoge desde 2002 la sede definitiva tras haber pasado por varios edificios desde su creación; siendo el primero la sede del NO-DO, situada en la calle Joaquín Costa de la capital (SORIA, 2005). Con este traslado, se amplió considerablemente el espacio para el almacenamiento de los fondos fílmicos, la colección de aparatos de cine y el servicio de documentación, y, además, se incrementó notablemente el espacio de acceso de los investigadores a los fondos de la biblioteca y del archivo gráfico y cinematográfico (PRADO, 2005), entre otros aspectos. Asimismo, desde 1989 cuenta con un espacio fijo dedicado a la exhibición y la difusión, el Cine Doré, muy próximo al anterior. Se trata también de un edificio histórico, de 1912, donde se unen el encuentro, el visionado, el debate y la divulgación, y que posee una librería especializada. En ella destacan desde guiones de películas a biografías de cineastas y actores, manuales sobre realización, análisis de filmes, o volúmenes sobre la historia del cine, entre otros contenidos. De esta manera, la filmoteca combina los fondos fílmicos con documentos de tipo bibliográfico, como libros o revistas, y de carácter publicitario, como carteles; una relevante colección de registros sonoros; y objetos 
relacionados con la producción cinematográfica, la evolución del cine y el considerado precine (PÉREZ LORENZO, 2011). Tiene también servicio de fototeca, compuesto por más de 500.000 fotografías, un laboratorio propio y una división de Difusión y Programación.

En tercer lugar, en 2012 se inauguró el Centro de Conservación y Restauración en la Ciudad de la Imagen, ubicada en la localidad madrileña de Pozuelo de Alarcón. Durante los años ochenta se percibió la necesitad de tener un espacio específico para poder conservar todos los materiales que contenía la filmoteca, y que estaban repartidos por distintos almacenes, debido a su volumen y constante crecimiento. Por ello, y "como el objetivo último de toda restauración es mantener las características de la obra, tal como fue exhibida originalmente, se consideraba fundamental la conservación de los materiales para que sus características fotográficas y sonoras se mantuvieran intactas" (DE LA FUENTE, 2015, p. 74). El complejo consta de varias partes, entre las que destaca el archivo destinado a las películas de nitrato de celulosa -las más inflamables-, que es subterráneo para garantizar las condiciones óptimas de mantenimiento de las 1.200.000 latas de celuloide que puede acoger. Consta de celdas climatizadas a una temperatura de entre doce y catorce grados, que están al $50 \%$ de humedad relativa, donde también se pueden encontrar materiales de las filmotecas regionales que carecen de instalaciones acondicionadas para la protección de los filmes realizados en este soporte. Asimismo, las películas plasmadas sobre materiales más seguros, como el acetato de celulosa o el poliéster, necesitan también unas condiciones climáticas muy concretas para su correcto almacenamiento, al igual que las emulsiones en blanco y negro o en color. Sin duda, "la idea central del diseño del archivo consistió en establecer y controlar los parámetros de las 4 variables básicas que fundamentan la estrategia de conservación: temperatura, humedad relativa, ventilación y estabilidad” (DE LA FUENTE, 2015, p. 75).

\section{El reto de la conservación}

En la puesta en valor del patrimonio cinematográfico existen tres cuestiones que determinan el proceso de salvaguardia de un filme: la recuperación, la restauración y la preservación. La primera de ellas tuvo un importante auge en la década de los setenta, cuando las filmotecas y los archivos cinematográficos iniciaron las primeras labores de búsqueda y localización de filmes perdidos, que en algunos casos estaban custodiados por parte de coleccionistas o de instituciones no especializadas. Así, con el propósito de recuperar los materiales, en la mayoría de los casos se suele proceder a la restauración por parte de las filmotecas, "para devolver a una película deteriorada sus condiciones originales, tal y como 
fue proyectada a los espectadores, tanto en su aspecto físico como en lo que se refiere a su contenido" (DEL VALLE GASTAMINZA, 2013, p. 123). En tercer lugar, la preservación se antoja como un paso decisivo para evitar el deterioro de las películas, y, por ello, lo más recomendable es su conservación en un entorno frío donde se den unas condiciones óptimas de temperatura y humedad. Junto a esta tarea, se halla la difusión de las mismas al público mediante la obtención de nuevas copias a partir de los materiales antiguos, tanto para proyección como en vídeo o DVD.

La Filmoteca Española tiene la misión de "recuperar, investigar y conservar el patrimonio cinematográfico y promover su conocimiento" (PÉREZ LORENZO, 2011, p. 173). La tarea de recuperación resulta fundamental para poder desarrollar el proceso, $\mathrm{y}$ comprende a su vez las labores de localizar, identificar y comprobar, es decir, encontrar la película que se sabe que está perdida, verificar el material y conocer en qué estado se halla para poder proceder, o no, a su restauración, y conservarla. En este cometido, las filmotecas han desarrollado desde la citada década en países como Suiza, Australia, Reino Unido, Estados Unidos, Italia o España -donde destacó la acción 'La Filmoteca Valenciana recupera nuestros recuerdos' y su eslogan 'Si tienes películas antiguas, llámanos. No dejes que el tiempo las destruya'-, diversas campañas para rescatar filmes o "para conseguir fondos que permitan la restauración y conservación del patrimonio recuperado" (VV.AA., 1995, p. 78). Los principales problemas a los que se enfrentan las películas son de tipo físico, es decir, relacionados con los daños causados en el soporte a causa de una manipulación incorrecta; de carácter biológico, producidos por una mala conservación debido a la humedad o el calor; o de tipo químico, que pueden provocar daños irreversibles en la película al afectar tanto al soporte como a la emulsión de la misma (DEL VALLE GASTAMINZA, 2013; HERNÁNDEZ PÉREZ, 2011). Sin duda, "la fragilidad de los soportes audiovisuales mantiene en jaque a una parte importante del patrimonio audiovisual mundial" (CARIDAD et al., 2011, p. 16).

El Centro de Conservación y Restauración -que "en un futuro se consolidará, [...] como uno de los pilares fundamentales sobre los que girará la preservación del patrimonio fúlmico español” (DE LA FUENTE, 2015, p. 73)-, acoge las tres funciones vitales de la institución: la preservación, la conservación y la restauración. La primera tiene el propósito de "facilitar el acceso al patrimonio" y conlleva una serie de pautas para proteger una película, como "la conservación, la duplicación, la restauración y la presentación o acciones que se realizan para difundir y compartir esos documentos con el público" (HERNÁNDEZ PÉREZ y CARIDAD SEBASTIÁN, 2011, p. 46). Sobre este aspecto, la FIAF establece una serie de 
pautas sobre las condiciones idóneas que debe tener el almacenamiento de películas, ya que el fin último del objetivo de conservación es el carácter histórico-patrimonial (HERNÁNDEZ PÉREZ, 2011). Actualmente, en la Filmoteca Española se conservan en torno a 400.000 latas con rollos de película.

En cuanto a la restauración, consta de tres fases fundamentales: el repaso, el lavado y la reproducción o tiraje de copias (VV.AA., 1995). Se trata de unas labores minuciosas y costosas que necesitan contar con personal cualificado para su correcta realización en los correspondientes laboratorios fílmicos. Sólo así se podrán eliminar la suciedad, las rayas, las roturas, el polvo o, incluso, los hongos presentes en las cintas debido al paso del tiempo, a las continuas manipulaciones o al incorrecto almacenaje. Sin embargo, y "aunque controlando las condiciones de uso y almacenamiento puede conseguirse una larga vida para las películas, no existen todavía materiales ni sistemas que garanticen su conservación definitiva" (VV.AA, 1995, p. 115). Sobre esta delicada materia, es necesario tener en cuenta lo siguiente para poder entender su complejidad:

\footnotetext{
La restauración va más allá de la copia física de los materiales e intenta reconstruir una versión específica de la película. A diferencia de lo que ocurre con la restauración de otro tipo de obras impresas y artísticas la restauración siempre implica duplicar el original. En documentación audiovisual en los procesos de conservación y restauración el principio básico es siempre no dañar el documento original y procurar que al final del proceso éste quede intacto. (HERNÁNDEZ PÉREZ Y CARIDAD SEBASTIÁN, 2011, p. 46).
}

Entre las principales colecciones de fondos fílmicos de la Filmoteca Española, están el Archivo Histórico de NO-DO -que se creó tras "un acuerdo de la Vicesecretaría de Educación Popular de 29 de septiembre de 1942 y una resolución de 17 de diciembre del mismo año (B.O.E. 22 de diciembre de 1942)" (SÁNCHEZ-BIOSCA y TRANCHE, 1993, p. 13) y hacía referencia a noticiarios y documentales-, y el Archivo de la Guerra Civil Española (1936-1939), cuyos fondos no se abrieron al público hasta 1976. La exhibición del primero tuvo carácter obligatorio desde su aparición hasta poco antes del fallecimiento de Francisco Franco el 20 de noviembre de 1975 -en concreto, mediante "una Orden del Ministerio de Información y Turismo de 22 de agosto de 1975 (B.O.E. de 19 de septiembre de 1975)" (SÁNCHEZ-BIOSCA y TRANCHE, 1993, p. 13)-, aunque se mantuvo su emisión hasta los primeros años de la Transición. Además, se impuso también en los cines de las colonias españolas, de manera que así se puede constatar su claro propósito de cohesión del territorio nacional mediante la propaganda, en este caso, audiovisual; una de las principales armas del franquismo. NO-DO pasó a formar parte de la Filmoteca Española tras una Orden de 20 de mayo de 1980 que se publicó en el B.O.E. de 11 de julio de ese mismo año. Su valor como 
documento histórico y social, por encima de su vinculación ideológica con el franquismo, le imprime un importante valor en lo que respecta a la identidad, la cultura y el patrimonio audiovisual:

\begin{abstract}
En realidad, las imágenes de NO-DO muestran, a quien quiera verlo, la huella no sólo de la posguerra española, sino también una huella de la memoria colectiva de casi cuarenta años. Si estas imágenes nos dicen hoy algo -y nos dicen mucho-, más allá de nuestras creencias políticas o nuestro diagnóstico histórico sobre la etapa franquista es porque encierran algo que debiera ser desentrañado, algo directamente relacionado con nuestras vivencias [...] Es necesario ser sensibles a un hecho: las imágenes de NO-DO nos hablan, nos interpelan más allá de la voluntad de sus artífices y, por supuesto, más allá de la ideología que las hizo nacer. (SÁNCHEZBIOSCA y TRANCHE, 1993, p. 18-19).
\end{abstract}

Por su parte, el Archivo de la Guerra Civil Española ha experimentado en las últimas décadas una notable demanda por parte de diferentes sectores, como la industria del cine, las cadenas de televisión o la investigación. Además, su proceso de búsqueda, recopilación, recuperación y archivo sigue en la actualidad (PÉREZ LORENZO, 2011). La Filmoteca Española también conserva "los negativos originales en soporte de nitrato y copias de películas de producciones de Cifesa, de Cesáreo González, del laboratorio Fotofilm SAE, de productores como José Luis Dibildos, Manuel José Goyanes y Luis Sanz, entre otros”, así como - tras su cese en 1976-, un material tan valioso como "las prácticas de los alumnos de la Escuela Oficial de Cine" (PRADO, 2005, p. 11).

A pesar de la importancia y la complejidad que suponen la catalogación, la restauración y el mantenimiento, hay que tener en cuenta que "se conserva para ver, para volver a ver, para revisar las obras y darles una segunda o tercera oportunidad, para reescribir permanentemente la historia del cine" (MARÍAS, 2005, p. 94-95). En esta labor, resulta fundamental la difusión del material audiovisual, en este caso, el cine.

\title{
El potencial educativo de la difusión del cine
}

Siguiendo los planteamientos de la FIAF, que se encaminan a "la colección, la conservación y la catalogación de las películas y de cualquier material documental relacionado con ellas" (DEL VALLE GASTAMINZA, 2013, p. 124), esta filmoteca tiene un compromiso con el valor cultural y su transmisión a la sociedad. Desde los setenta $-\mathrm{y}$ coincidiendo con el final del franquismo-, la institución comenzó una etapa marcada por la intervención activa en la recuperación de películas. Este propósito se ha realizado mediante la adquisición de filmes a particulares y a coleccionistas, y el acercamiento a las distintas 
empresas cinematográficas para que accedieran a depositar sus negativos $u$ otros materiales en ella (PRADO, 2005). Así, SORIA (2005, p. 34) asegura:

\begin{abstract}
Una filmoteca, como cualquier museo o archivo, se vivifica con el oxígeno que le proporciona su presencia en el exterior. La difusión de sus fondos o de los préstamos que pudieran obtenerse resulta, por lo tanto, muy conveniente. Es como un museo: si sus tesoros están cerrados a cal y canto al público, tiene mucho más difícil no sólo el ejercicio pleno de sus funciones, sino también las posibilidades de su futuro. Igualmente, si una filmoteca ejerce actividades de difusión, no sólo crea un ambiente favorable en la opinión pública por su servicio a la cultura cinematográfica, sino que promueve actividades más positivas por parte de la Administración.
\end{abstract}

Su labor conservadora se completa con una interesante y necesaria actividad de difusión, que, al principio -y quizá por el desconocimiento de cómo debía funcionar una filmoteca-, tomó como modelo la realizada desde los museos, por una parte, y desde los archivos y bibliotecas, por otra (MARÍAS, 2005). En este sentido, y teniendo en cuenta el enriquecimiento que supone la cultura del cine, destaca en primer lugar su biblioteca especializada -de uso público, gratuita y principalmente enfocada al trabajo de críticos, investigadores e historiadores-, que, por su diversidad, "se puede considerar el Centro de Documentación Cinematográfica más importante del país" (SANTAMARINA, 2005, p. 157). Asimismo, el exuberante archivo gráfico -compuesto por numerosas colecciones que suman más de medio millón de fotografías vinculadas directamente al cine, carteles, programas de mano o guías de películas, entre otros muchos elementos-, y la profusa pero delicada fonoteca -que atesora más de 6.000 documentos sonoros desde la década de los veinte hasta la actualidad, y en soportes variados-, constituyen otros dos puntos fuertes de la institución en lo que a fondos para la difusión se refiere.

En tercer lugar, sobresale la Colección, creada para la construcción del futuro Museo del Cine, que reúne más de 22.000 piezas vinculadas a la fotografía, el llamado precine y el cine, como daguerrotipos, linternas mágicas y proyectores, respectivamente (SANTAMARINA, 2005). Esta exhibición de objetos y de materiales cinematográficos constituye la exposición permanente de la filmoteca, que, sin duda, se convertirá en uno de de sus principales atractivos cuando este espacio museístico sea una realidad. A este respecto destaca el acuerdo que recientemente han firmado el ministro de Educación, Cultura y Deporte, Íñigo Méndez de Vigo, y la presidenta de la Academia de las Artes y las Ciencias Cinematográficas de España, Yvonne Blake, para la creación del mismo (EUROPA PRESS, 2017). Esto permitiría impulsar la labor de la filmoteca por parte de estas dos instituciones y repercutiría en la búsqueda de otras piezas, la configuración de nuevas exposiciones y la localización de un espacio específico para este fin. Sin duda, el Museo del Cine se convertiría 
en uno de los espacios de referencia de la filmoteca para la preservación y la difusión del cine español, y, a la vez, el impacto que tendría en la sociedad le daría también una importante visibilidad como entidad fílmica.

Del mismo modo, la faceta editorial de la institución se ha consolidado en las últimas tres décadas, y las obras investigadoras que suele patrocinar o coeditar-como, por ejemplo, con el Festival de Cine de San Sebastián-, también se han afianzado. En esta línea destacan la colección Cuadernos de la Filmoteca-dedicada a la divulgación de textos relacionados con la conservación y la restauración-, filmografías de cineastas, monografías o catálogos, entre otros estudios, "que se han convertido en textos básicos y fundamentales dentro de la historiografía española" (SANTAMARINA, 2005). Por otra parte, la filmoteca también desarrolla iniciativas con una clara finalidad científica, divulgativa y educativa, como seminarios y mesas redondas con expertos, además de las presentaciones de sus libros. Asimismo, desde 1990 organiza talleres de formación para restauradores, catalogadores y documentalistas que se dirigen al personal especializado que trabaja en las filmotecas del territorio nacional (DEL AMO, 1995; VV.AA., 1995).

En cuanto a la exhibición, el Cine Doré acoge más de 1.200 proyecciones al año, en el marco de una programación variada que pretende redescubrir a los pioneros, a clásicos del cine y a directores contemporáneos; promocionar el conocimiento del cine español con la incorporación de títulos de cineastas no muy conocidos u olvidados, así como del cine latinoamericano; fomentar la presencia de cinematografías de vanguardia; o difundir filmes de cinematografías extranjeras que tienen poca presencia en los cauces de la exhibición española; entre otras iniciativas (SANTAMARINA, 2005). Asimismo, también programa varios ciclos, películas pertenecientes a retrospectivas especiales o, incluso, los reestrenos de filmes recién recuperados o restaurados. Estas proyecciones suelen ser bastante enriquecedoras para los espectadores cuando cuentan con coloquios a cargo de especialistas o profesionales vinculados a la película en cuestión. Sin duda, la unión entre visionado y diálogo favorece el acercamiento de la obra al público, es decir, del patrimonio cinematográfico. Este espacio, que consta de tres salas -la original, una moderna más funcional y la terraza de verano, denominada Sala Luis García Berlanga-, suele exhibir de tres a cinco películas diarias. Igualmente, esta filmoteca colabora de forma estrecha con las autonómicas y con otras pertenecientes a la FIAF, así como con cadenas de televisión -sobre todo públicas-, empresas audiovisuales, productoras de cine, museos y Universidades. De esta manera, facilita la consulta y el visionado de sus archivos cinematográficos, e incluso permite la compra de 
derechos de los mismos para su uso en proyectos audiovisuales de diversa índole (PÉREZ LORENZO, 2011).

La incorporación de materiales audiovisuales en el aula, tanto en escuelas de Educación Infantil y de Primaria como en Institutos de Educación Secundaria, Ciclos Formativos o Universidades, permite también difundir el patrimonio fílmico de forma didáctica y académica. Supone, además, la transmisión a la sociedad y, en concreto, a los alumnos más jóvenes, de unas películas que forman parte de la historia del cine -español e internacional-, y ayudan a completar el estudio de las distintas materias. De esta manera, el interesante, necesario y decisivo trabajo de difusión que desempeñan las filmotecas, se puede complementar con el desarrollado en los centros educativos. El acercamiento de la Filmoteca Española a la sociedad, la necesidad de conocer, estudiar y analizar su patrimonio, y el compromiso de las instituciones educativas por incorporar la historia del cine en la enseñanza, componen un triple eje que resulta decisivo para la difusión de películas que no deben quedar relegadas al conocimiento de los expertos, sino que también deben formar parte de la cultura popular. Así, se considera que la tarea conjunta de la filmoteca con las instituciones educativas, mediante visionados, visitas guiadas, emisión de materiales, prácticas de alumnos, talleres, exposiciones temáticas y conmemorativas, y encuentros con protagonistas y eruditos del cine, es imprescindible para que los estudiantes puedan aprender y disfrutar de un patrimonio cinematográfico que constituye, y construye, su identidad. Además, "si el encuentro con el cine no se produce en la escuela, hay muchos niños para quienes es muy probable que no se produzca jamás" (BERGALA, 2007, p. 36). En este sentido, especialmente interesantes y novedosas podrían resultar las relaciones de la filmoteca con los museos pedagógicos (ÁLVAREZ DOMÍNGUEZ, 2016), pues en ellos podemos encontrar unos potenciales aliados para poder difundir y poner en valor al cine como patrimonio de la humanidad.

Por otra parte, resulta imprescindible que la documentación de los filmes en las filmotecas esté detallada y cuente con información relevante y precisa, con el objetivo de facilitar a investigadores, estudiantes, usuarios, y la ciudadanía en general, el acceso a su localización y contenido (DOMÍNGUEZ-DELGADO y LÓPEZ-HERNÁNDEZ, 2016; MIMOSA y PATÓN RODRÍGUEZ, 2014). En este sentido, “corresponde a los especialistas y profesionales determinar las directrices y actuaciones más adecuadas y eficientes para su correcta conservación, protección y difusión; y a las autoridades políticas y administrativas, sistematizarlas en normativas y procedimientos que pueden ser respetados y compartidos por todos" (RODRÍGUEZ ORTEGA, 2011, p. 28). Sin duda, resulta necesario reiterar la idea de 
que "si se conserva un determinado bien cultural es justamente para difundirlo o, cuando menos, para hacerlo accesible a quienes puedan estar interesados en conocerlo o disfrutarlo" (PÉREZ MILLÁN, 2005, p. 78).

Por último, se considera oportuno rescatar la siguiente declaración, para que las filmotecas y los espectadores reflexionen sobre el necesario papel que debe ocupar el cine clásico en el presente: "es importante, para mantener con vida el cine del pasado capaz de tenerse en pie, que coexista y pueda confrontarse con el más reciente, con el que se está haciendo ahora, con el que se vislumbra para el futuro" (MARÍAS, 2005, p. 95). Así, y como sucede en otras disciplinas y expresiones artísticas, la mirada al ayer resulta fundamental para entender el hoy y poder construir el mañana. Por ello, tomando como base las posibilidades y retos a los que se enfrenta del patrimonio histórico-educativo en la sociedad actual, se puede afirmar que el patrimonio cinematográfico "se comunica, se aprende, se interioriza, se vive y se siente. Lo necesitamos para saber quiénes somos, para saber qué somos" (ÁLVAREZ DOMÍNGUEZ, 2016, p. 30).

\section{REFLEXIONES FINALES}

El patrimonio audiovisual, tanto de carácter fílmico como cinematográfico, televisivo o sonoro, posee un valor histórico, artístico y social que lo convierte en un bien cultural fundamental en la sociedad actual. Además, permite conocer el pasado de una sociedad o comunidad determinada, crear imaginarios colectivos que ayudan a entender el mundo $\mathrm{y}$, al convertirse en una importante fuente de información, incentivar la investigación científica para la reflexión y el conocimiento de la ciudadanía.

El cine, tanto en filmes de ficción como en documentales, refleja cómo era la sociedad, la cultura y, en definitiva, la vida en etapas pasadas, o cómo se representaba en función de criterios políticos, religiosos o propagandísticos. Por ello, ostenta un papel relevante como testimonio y memoria que, sin duda, debe preservarse. En este sentido, el denominado séptimo arte ayuda a fortalecer el sentimiento de pertenencia a una sociedad y el concepto de identidad nacional (DÍAZ CERVANTES, 2014).

Las diversas funciones dedicadas a la protección del patrimonio audiovisual se pueden resumir en dos cuestiones clave: el acceso y la preservación. La primera permite llegar al objeto y presentarlo, y la segunda garantiza su conservación y mantenimiento, favoreciendo así, de nuevo, el acceso a otros espectadores, estudiosos o analistas. De esta manera, junto a la importante tarea de la restauración, el papel de las filmotecas va un paso más allá con respecto 
al de otros espacios enfocados a la salvaguarda de este patrimonio, como, por ejemplo, las bibliotecas o los museos. Así, se puede afirmar que casi la totalidad de las películas conservadas desde los inicios del cine -especialmente en el caso español-, han llegado hasta nuestros días gracias a la labor de las filmotecas.

La Filmoteca Española se encarga de salvaguardar el patrimonio de nuestra memoria, y de no ser por su labor, las generaciones actuales no hubieran podido conocer las obras recuperadas (MARÍAS, 2005). Esta idea es extensible a las generaciones futuras, ya que todo el trabajo realizado por parte de esta institución con las películas que forman parte de la memoria audiovisual -por su valor artístico, social e histórico-, tiene el cometido de conservarlas para protegerlas y poder volver a visionarlas. Así, el espectador que las conoce puede disfrutar de nuevo de ellas, y el que no, descubrirlas, pues forman parte del patrimonio audiovisual y, en definitiva, cultural. Además, llevarlo al ámbito educativo - tanto al colegio, como a los institutos de Educación Secundaria o a la Universidad-, se antoja fundamental para que los jóvenes puedan conocer su pasado fílmico y compararlo con el de otros países y con el presente cinematográfico.

Este estudio puede aplicarse a otras filmotecas, tanto españolas como extranjeras, con la finalidad de conocer el trabajo realizado en ellas, y así poder mostrar una comparativa con respecto al caso español. En este sentido, sería interesante analizar a la francesa, la británica o la portuguesa, entre otras destacadas, pero también, a las ubicadas en algunos países de América Latina, como las de México. Por otra parte, un estudio dedicado a las filmotecas autonómicas permitiría indagar en la filosofía, valores y objetivos de cada una, y, además, observar sus relaciones con la Filmoteca Española. Por último, también sería oportuno realizar una aproximación a los Museos del Cine y a la labor que desempeñan las Universidades en la difusión del patrimonio audiovisual.

\section{REFERENCIAS}

Álvarez DOMÍNGueZ, P. Los Museos Pedagógicos en España: actualidad y perspectivas de futuro. En: ÁLVAREZ DOMÍNGUEZ, P. Los Museos Pedagógicos en España. Entre la memoria y la creatividad. Gijón/Sevilla: Ediciones Trea/Editorial Universidad de Sevilla, 2016, 21-32 p.

BergalA, A. La hipótesis del cine. Pequeño tratado sobre la transmisión del cine en la escuela y fuera de ella. Barcelona: Laertes, 2007, $206 \mathrm{p}$.

CARIDAD, M., HERNÁNDEZ, T., RODRÍGUEZ, D. y PÉREZ, B. Documentación audiovisual. Madrid: Editorial Síntesis, 2011, 231p. 
CEBRIÁN HERREROS, M. Prólogo. En: CARIDAD, M., HERNÁNDEZ, T., RODRÍGUEZ, D. y PÉREZ, B. Documentación audiovisual. Madrid: Editorial Síntesis, 2011, $9-14 \mathrm{p}$.

DE LA FUENTE, M. El centro de conservación y restauración de la filmoteca española. Conservando nuestra memoria. Patrimonio cultural de España, 10, 2015, 73-82 p.

DEL AMO, A. Características y circunstancias del trabajo de conservación cinematográfica. En: VV.AA. La imagen rescatada. Recuperación, conservación y restauración del Patrimonio Cinematográfico. Valencia: Filmoteca Generalitat Valenciana, $1995,15-17 \mathrm{p}$.

DEL VALLE GASTAMINZA, F. Patrimonio cinematográfico. En: MARCOS RECIO, J. C. (coord.): Gestión del patrimonio audiovisual en medios de comunicación. Madrid: Editorial Síntesis, 2013, 111-129 p.

DÍAZ CERVANTES, K. Preservar el patrimonio audiovisual para fortalecer nuestra identidad nacional. Congreso ALAIC, Perú, 2014, Disponible en: $<$ http://congreso.pucp.edu.pe/alaic2014/wp-content/uploads/2013/09/gt11-katherine-diazcervantes.pdf $>$. Consultado en: 03.03.2017.

DOMÍNGUEZ-DELGADO, R. y LÓPEZ HERNÁNDEZ, M. A. Análisis documental del contenido fílmico en seis filmotecas españolas. El profesional de la información, (25), 5, 2016, 787-794 p. Disponible en: $<$ http://www.elprofesionaldelainformacion.com/contenidos/2016/sep/09_esp.pdf $>$.

Consultado en: 03.03.2017.

EDMONSON, R. Filosofía y principios de los archivos audiovisuales. París, UNESCO, (CI, 2004/WS/2), 2004. 201 Disponible $<$ http://unesdoc.unesco.org/images/0013/001364/136477s.pdf $>$. Consultado en: 09.03.2017.

EUROPA PRESS. La creación de un museo del cine, cada vez más cerca. Barcelona: La Vanguardia, 2017 (01.02.2017). Disponible $<$ http://www.lavanguardia.com/cultura/20170201/413912108040/creación-museo-cine.html>. Consultado en: 10.03.2017.

EFE. El cine... ¿Patrimonio de la Humanidad? Madrid: ABC, 2013 (22.04.2013). Disponible en: $\quad<$ http://hoycinema.abc.es/noticias-cine/20130422/cine-patrimonio-humanidad608006.html>. Consultado en: 09.03.2017.

HERNÁNDEZ PÉREZ, T. La documentación audiovisual. En: CARIDAD, M., HERNÁNDEZ, T., RODRÍGUEZ, D. y PÉREZ, B. Documentación audiovisual. Madrid: Editorial Síntesis, 2011, 19-43 p.

HERNÁNDEZ PÉREZ, T. y CARIDAD SEBASTIÁN, M. Preservación y digitalización de la documentación audiovisual. En: CARIDAD, M., HERNÁNDEZ, T., RODRÍGUEZ, D. y PÉREZ, B. Documentación audiovisual. Madrid: Editorial Síntesis, 2011, 45-65 p.

MARCOS RECIO, J. C. (coord.). Gestión del patrimonio audiovisual en medios de comunicación. Madrid: Editorial Síntesis, 2013, 221 p. 
MARÍAS, M. (2005). Las misiones de una Filmoteca y su futuro. En: SANTAMARINA, A. Filmoteca Española. Cincuenta años de historia. Madrid: Filmoteca Española, Instituto de la Cinematografía de las Artes Audiovisuales (ICAA) y Ministerio de Cultura, 2005, 83-99 p.

MIMOSA, B. y PATÓN RODRÍGUEZ, N. Patrimonio Audiovisual: tipologías y su desarrollo. Salamanca: ArchivPost, Asociación de Archiveros de Castilla y León, 2014. Disponible en: <http://www.acal.es/index.php/archivpost-a-fondo $>$. Consultado en: 03.03.017.

PÉREZ LORENZO, B. Fuentes para la producción audiovisual. En: CARIDAD, M., HERNÁNDEZ, T., RODRÍGUEZ, D. y PÉREZ, B. Documentación audiovisual. Madrid: Editorial Síntesis, 2011, 167-197 p.

PÉREZ MILLÁN, J. A. De la Filmoteca Nacional al florecimiento de las Autonómicas (1984-1986). En: SANTAMARINA, A. Filmoteca Española. Cincuenta años de historia. Madrid: Filmoteca Española, Instituto de la Cinematografía de las Artes Audiovisuales (ICAA) y Ministerio de Cultura, 2005, 67-81 p.

PIQUERAS, M. J. La fragilidad de la memoria. En: VV.AA. La imagen rescatada. Recuperación, conservación y restauración del Patrimonio Cinematográfico. Valencia: Filmoteca Generalitat Valenciana, 1995, 7-9 p.

PRADO, J. M. Claves para un cincuentenario. En: SANTAMARINA, A. Filmoteca Española. Cincuenta años de historia. Madrid: Filmoteca Española, Instituto de la Cinematografía de las Artes Audiovisuales (ICAA) y Ministerio de Cultura, 2005, 9-18 p.

RODRÍGUEZ ORTEGA, N. El patrimonio fílmico y cinematográfico. Cuestiones para una reflexión abierta. En: SAURET GUERRERO, T., RUIZ SAN MIGUEL, J., GÓMEZ GÓMEZ, A. J., y CHAVES GUERRERO, E. I. (ed.): El cine español: arte, industria y patrimonio cultural. Málaga: Ministerio de Cultura, Instituto de Cinematografía y de las Artes Audiovisuales (ICAA) y Servicio de Publicaciones de la Universidad de Málaga, 2011, 15-28 p.

SÁNCHEZ-BIOSCA, V. y TRANCHE, R. R. NO-DO: El tiempo y la memoria. Cuadernos de la Filmoteca (1). Madrid: Filmoteca Española. Instituto de la Cinematografía y de las Artes Audiovisuales. Ministerio de Cultura, 1993, 55 p.

SANTAMARINA, A. Filmoteca Española. Cincuenta años de historia. Madrid: Filmoteca Española, Instituto de la Cinematografía de las Artes Audiovisuales (ICAA) y Ministerio de Cultura, 2005, 240 p.

SORIA, F. Los primeros treinta años: una larga carrera de obstáculos. En: SANTAMARINA, A. Filmoteca Española. Cincuenta años de historia. Madrid: Filmoteca Española, Instituto de la Cinematografía de las Artes Audiovisuales (ICAA) y Ministerio de Cultura, 2005, 21-57 p.

UNESCO. Actas de la Conferencia General. 21.a reunión Belgrado, 23 de septiembre-28 de octubre de 1980. Volumen 1 Resoluciones. París: UNESCO, 1981. Disponible en: $<$ http://unesdoc.unesco.org/images/0011/001140/114029s.pdf $>$. Consultado en: 27.02.2017. 
VALDÉS, J. A. El cine como patrimonio en México. Cinema Red. México: Grupo Radio Centro, 2015. Disponible en: $<$ http://redfm921.com/columnas/el-cine-como-patrimonio-enmexico.html>. Consultado en: 09.03.2017.

VV.AA. La imagen rescatada. Recuperación, conservación y restauración del Patrimonio Cinematográfico. Valencia: Filmoteca Generalitat Valenciana, 1995, 133 p. 